\title{
Antagonistic effect of indigenous skin bacteria of brook charr (Salvelinus fontinalis) against Flavobacterium columnare and F. psychrophilum
}

\author{
Sébastien Boutin ${ }^{\mathrm{a}, *}$, Louis Bernatchez ${ }^{\mathrm{a}}$, Céline Audet ${ }^{\mathrm{b}}$, Nicolas Derôme ${ }^{\mathrm{a}}$ \\ ${ }^{a}$ Institut de Biologie Intégrative et des Systèmes (IBIS), Département de Biologie, Université Laval, 1030 Avenue de la Médecine, Québec (Québec), Canada G1V 0A6 \\ ${ }^{\mathrm{b}}$ Institut des sciences de la mer de Rimouski (ISMER), Université du Québec à Rimouski (UQAR), 310 allée des Ursulines, Rimouski (Québec), Canada G5L 3A1
}

\section{A R T I C L E I N F O}

\section{Article history:}

Received 28 June 2011

Received in revised form 29 August 2011

Accepted 1 September 2011

\section{Keywords:}

Probiotics

Flavobacterium

Salvelinus fontinalis

Competitive exclusion

\begin{abstract}
A B S T R A C T
Industrial fish production exposes fish to potentially stressful conditions, which in turn may induce infections by opportunistic pathogens. Probiotics appear to be a promising way to prevent opportunistic infections in aquaculture. In this study, we tested the inhibitory potential of endogenous bacterial communities found in the mucus of brook charr (Salvelinus fontinalis) against two major pathogens Flavobacterium columnare and Flavobacterium psychrophilum. Nine bacterial strains were isolated from brook charr skin mucus and tested for potential antagonistic activity. Results from both agar diffusion assays and broth co-culture assays showed the presence of antagonism. We identified seven bacterial strains, collected from unstressed fish, which exerted strong antagonism against $F$. psychrophilum and/or F. columnare. These strains were mixed and used to treat columnaris disease in an in vivo experiment in which four distinct fish families were tested. This treatment resulted in a decrease of mortality (54-86\%) across fish families indicating that candidates from the host microbiota are potentially suitable for probiotic development. This would allow for the efficient (ability to adhere and colonize the host mucus) and durable management (antagonistic effect against pathogens which would be harmless for the host and safe for its environment) of opportunistic diseases in aquaculture.
\end{abstract}

(c) 2011 Elsevier B.V. All rights reserved.

\section{Introduction}

Over the last decade, the aquaculture industry has greatly intensified productivity and is now a major economic activity in many countries (FAO, 2007). Massive production in fish farms may expose fish to stressful conditions, which in turn has the potential to induce infection by opportunistic pathogens (Wakabayashi, 1991). Infections are usually prevented and controlled by intrusive veterinary medicines and chemical substances (Rangdale et al., 1997). However, the beneficial effects of antimicrobial agents are counterbalanced by selection for

\footnotetext{
* Corresponding author. Tel.: +1 418656 2131/6785; fax: +1 4186567176 .

E-mail address: sebastien.boutin.1@ulaval.ca (S. Boutin).
}

resistant pathogens (Nematollahi et al., 2003). Therefore, alternative strategies to prevent opportunistic infections in aquaculture are strongly needed. The development of probiotics appears to be one of the most promising ways to reach this goal (Merrifield et al., 2010).

The present study focused on two important opportunistic pathogens in Brook charr (Salvelinus fontinalis), namely Flavobacterium columnare and Flavobacterium psychrophilum (Bernardet and Bowman, 2006). Skin microflora was targeted as a potential source of probiotics because isolates from other parts of the body (e.g., gut) are known to be inefficient at inhibiting the growth of skin pathogens (Spanggaard et al., 2001). Microbial communities are sensitive to various stressful environmental conditions (Schimel et al., 2007). In this respect, we hypothesized that stress may imbalance the bacterial community structure of brook charr skin mucus and 
trigger opportunistic infections. Therefore, our general aim was to test whether natural isolates of non-stressed skin mucus bacterial community exhibit an antagonistic effect against two pathogens $F$. columnare and F. psychrophilum.

The specific objectives were: (i) to test the presence of inhibitory compounds in brook charr skin mucus; (ii) to evaluate the competitiveness of eight microbial isolates from skin mucus against $F$. columnare and $F$. psychrophilum for nutrients, (iii) to determine which defensive mechanism was exerted, i.e., competitive exclusion or synthesis of antimicrobial substances, (iv) to confirm the in vitro effectiveness of our candidates on an in vivo experiment for aquaculture application.

\section{Experimental procedure}

\subsection{Sampling of brook charr bacterial community}

Sixteen fish families derived from crosses between different parents were raised at the Laboratoire Régional des Sciences Aquatiques (LARSA) at Université Laval, in Quebec City, QC. Among them, two families were collected from a stress experiment. A total of two individuals per family were sampled. One of them was previously exposed to stressful physiological conditions (hypoxia and handling). Skin mucus was sampled using a sterile razor blade and homogenized after addition of $9 \mathrm{~mL}$ sterile water.

\subsection{Identification of the bacterial isolates}

Fish mucus was diluted in sterile water from a 10 fold to a $10^{-7}$ dilution. Dilutions were spread on TSA and R2A media (Difco). Bacterial colonies were isolated and individualized by cross streaking and incubated at $20^{\circ} \mathrm{C}$ for $48 \mathrm{~h}$. A total of nine isolates were identified by $16 \mathrm{~S}$ rDNA sequencing. Colonies were used as template DNA for PCR amplification of the 16S rRNA gene using the universal bacterial primers 63F (5'-CAGGCCTAACACATGCAAGTC-3') (Marchesi et al., 1998) and 907R (5'-CCGTCAATTCMTTTRAGTTT-3') (Lane et al., 1985). PCRs were carried out in a volume of $25 \mu \mathrm{L}$ containing $0.2 \mathrm{mM}$ dNTP (Promega), $0.3 \mu \mathrm{M}$ each primer, $6.4 \mu \mathrm{g}$ of BSA, $1.25 \mathrm{mM}$ of $\mathrm{MgCl}_{2}, 1 \times$ of Buffer and $0.4 \mathrm{U}$ of Taq DNA polymerase (Promega) and performed in a Biometra T1 Thermocycler. The following amplification conditions were applied: a first step of initial denaturation at $94{ }^{\circ} \mathrm{C}$ for 5 min followed by 28 cycles of $94{ }^{\circ} \mathrm{C}$ for $1 \mathrm{~min}, 55^{\circ} \mathrm{C}$ for $1 \mathrm{~min}, 72^{\circ} \mathrm{C}$ for $90 \mathrm{~s}$ and a final extension step at $72{ }^{\circ} \mathrm{C}$ for $10 \mathrm{~min}$. PCR products were visualized by agarose gel electrophoresis $[0.8 \%(\mathrm{w} / \mathrm{v})$ agarose, $100 \mathrm{~V}]$. Fragments were sequenced using the big Dye terminator V3 chemistry on an ABI 3130XL sequencer (Applied Biosystem, Foster City) at the Plateforme d'analyse Biomoleculaire (IBIS, Laval University).

\subsection{Media used for culture and competition assay}

Three general growth media, R2A (Difco) and TSA (Difco) were used for isolation, identification, and culture of brook charr bacterial community isolates. Both pathogens were grown on their respective general growth media, i.e., Anacker and Ordal (AO) (Anacker and Ordal,
1959). This media was used for competition assays with pathogens, F. columnare (ATCC 49418) and F. psychrophilum (ATCC 49512) isolated from Oncorhynchus kisutch and Salmo trutta (Bernardet and Grimont, 1989).

\subsection{Screening for antagonistic effect in agar diffusion assay}

All host bacterial isolate strains were tested for antagonistic effects using well diffusion assays against $F$. columnare and F. Psychrophilum. Melted AO cooled to $45^{\circ} \mathrm{C}$ was inoculated with each pathogen to a final density of $10^{6}$ cells $\mathrm{mL}^{-1}$ agar and poured into Petri dishes (Gram and Melchiorsen, 1996). A volume of $10 \mu \mathrm{L}$ of probiotic candidate culture was added into a $3 \mathrm{~mm}$ well punched in the solidified agar plates. Plates were incubated at $20^{\circ} \mathrm{C}$ and observed for zones of growth around the wells during $48 \mathrm{~h}$ (Spanggaard et al., 2001). Individual strains exhibiting competition capabilities were then mixed in three cocultures: two co-cultures containing the same quantity of all strains with specific antagonistic effect against each pathogen $F$. columnare and $F$. psychrophilum (culture $C$ and culture $\mathrm{P}$ ) and one co-culture with all strains with antagonistic effect against the two pathogens (culture $\mathrm{U})$. These three co-cultures $(30 \mu \mathrm{L}$ ) were added into $3 \mathrm{~mm}$ wells punched in the solidified agar plates, and observed for zones of growth around the wells during $48 \mathrm{~h}$ to check potential synergistic co-culture effects (Timmerman et al. 2004).

\subsection{Screening for antagonistic effect in broth co-culture assay}

All antagonistic effects observed in the diffusion agar assay were validated by a broth co-culture assay. Candidates $\left(10^{4}\right.$ cells) were added to $1 \mathrm{~mL}$ of AO media in competition with $10^{4}$ cells of the pathogen. These cocultures were made in triplicates and incubated $48 \mathrm{~h}$ at $20^{\circ} \mathrm{C}$. Two mono-cultures of $10^{4}$ cells of each pathogen acted as controls. Growth of both candidates and pathogens was observed by spreading the co-culture on AO agar plate along with morphological identification and counting.

\subsection{Screening for antagonistic effect of mucus proteins}

Forty-three fish were sampled and all mucus samples were mixed and sterilized with UV light for $25 \mathrm{~min}$ to minimize degradation of proteins (Williams and Kraus, 1963). Forty-five microliter of mucus were added to $5 \mu \mathrm{L}$ (500 cells) of pathogen culture in AO, spread on AO agar plate and incubated at $20^{\circ} \mathrm{C}$ for $48 \mathrm{~h}$. After incubation, culture was spread on AO agar to observe the growth of pathogen. A volume of $45 \mu \mathrm{L}$ of PBS mixed with $5 \mu \mathrm{L}$ of pathogen culture acted as control.

\subsection{Probiotic treatment of fish infection}

Seven strains selected for their antagonistic activity during the in vitro experiment were tested together in a coculture for logistical reasons. Four different fish families (i.e., resulting from different parental crosses), all selected on the basis of zootechnical traits of interest (growth and 
reproduction) were used for the in vivo experiment (S1, S5, S9, S10). Each family was equally split up into four tanks: one pair of test tanks and one pair of control tanks. Although each tank pair shared the same water recirculation system, fish in separated tanks could not transmit pathogens by skin contact. Therefore, tanks supplied with the same water recirculation system were deemed as test pseudo-replicates. Test and control tank pairs were separated in two different units (i.e., supplied with independent water recirculation systems). All of the individuals were juveniles (mean size: $12.2 \pm 1.4 \mathrm{~cm}$; mean weight: $16 \pm 5.8 \mathrm{~g}$ ) and came from the "Station aquicole de l'Institut des sciences de la mer de Rimouski". Fish were raised at $12{ }^{\circ} \mathrm{C}$ and oxygen concentration was always higher than $12 \mathrm{mg} / \mathrm{L}$. Each tank contained between 103 and 110 fish. Two weeks after transport to LARSA, the first symptoms of columnaris disease appeared in all tanks and we started the addition of the mix of probiotics candidates. The probionts were added in the two test tanks to reach the concentration of $10^{5} \mathrm{cell} / \mathrm{mL}$ in water twice daily until the fish mortality stabilized. Dead fish and moribund were checked for clinical symptoms of columnaris disease. The moribund fish were euthanized with MS-222 as required by the "Comite de Protection des Animaux de l'Université Laval (CPAUL, http:// www.vrr.ulaval.ca/deontologie/cpa/index.html?accueil).

\subsection{Statistical analysis}

We compared the percentage of death between test and control during 21 days using a generalized linear model approach with a logit link and a binomial distribution. The analysis was performed using the software $R$, version 2.12.2.

\section{Results}

\subsection{Screening of the endogenous brook charr skin microbiota}

A total of nine bacterial colonies were identified by $16 S$ rDNA gene sequence analysis (Table 1 ). Among the nine strains, six were found in mucus cultures isolated from both stressed and non-stressed fish. Actinobacteria (Microbacteriaceae, Nocardiaceae and Dietziaceae) was the predominant (six strains) bacterial group that was isolated from skin mucus. Proteobacteria (gamma and alpha subclass) was the second group isolated (three strains). Both of these groups belong to gram-negative bacteria and were isolated from skin on TSA, while Microbacteriaceae and Pseudomonadaceae were isolated with R2A only.

All strains except Pseudomonas peli were able to grow on AO agar and could then be tested as probiotic candidates against $F$. columnare and F. psychrophilum as those two pathogens only grow on AO agar.

\subsection{Screening for antagonistic effect of probiotic candidate in agar diffusion assay}

The eight strains were screened for antagonistic effects with an agar diffusion assay against the two pathogens, $F$. columnare and F. psychrophilum (Table 1 ). In all assays, growth circles were observed, and no inhibitory zones involving antimicrobial compounds were found. Six strains (75\% of the cultivable skin fish microflora: Luteimonas aestuarii, Rhodococcus cercidiphylli, Microbacterium oxydans, Rhodococcus qingshengii, Sphingopyxis bauzanensis, Dietzia maris) were more competitive (exhibited better growth) than $F$. psychrophilum after a $48 \mathrm{~h}$ incubation period. All strains isolated from unstressed fish exhibited competitive capabilities against F. psychrophilum. Four strains (50\% of the cultivable mucosal microflora: Luteimonas aestuarii, Rhodococcus qingshengii, Leucobacter luti, Dietzia maris) were more competitive than F. columnare. The specific co-cultures ( $\mathrm{C}$ and $\mathrm{P}$ ) were still competitive against the two pathogens, but no synergetic effect was observed $(p>0.05)$. The co-culture U exhibited a stronger inhibitory effect $(p=0.015)$ when compared to the expected mean value of mono-cultures. This can be associated to the growth of Microbacterium oxydans in mono-cultures. Indeed, all the strains included in the coculture had similar growth in mono-culture $(1.5 \pm 0.5 \mathrm{~mm})$ except Microbacterium oxydans, which had an extensive growth in mono-culture $(23 \mathrm{~mm})$.

\subsection{Validation of antagonistic effect in broth co-culture assay}

In order to validate the presence of a competitive effect, the seven strains exhibiting antagonistic effects were tested in broth co-culture assays with the pathogens. All candidates grew but no cells of pathogens were found after

Table 1

16S rDNA gene sequence identification and capability to inhibit growth in nine indigenous bacterial isolates from mucus skin of brook charr. All strains were found in mucus from unstressed fish but only 6 were found in mucus from stressed fish (+), isolates grew; (-), isolates did not grow.

\begin{tabular}{|c|c|c|c|c|c|c|c|}
\hline Isolates & Media & $\begin{array}{l}\text { Physiological } \\
\text { condition of host }\end{array}$ & Bacterial group & $\begin{array}{l}\text { Closest hit } \\
\text { in GenBank }\end{array}$ & $\begin{array}{l}\text { Percentage } \\
\text { similarity }\end{array}$ & $\begin{array}{l}\text { Growth on } \\
\text { Flavobacterium } \\
\text { columnare } \\
\text { culture }\end{array}$ & $\begin{array}{l}\text { Growth on } \\
\text { Flavobacterium } \\
\text { psychrophilum } \\
\text { culture }\end{array}$ \\
\hline $\mathrm{CP} 1$ & TSA & UnStressed & Gamma-proteobacteria & Luteimonas aestuarii & 98.899 & + & + \\
\hline $\mathrm{CP} 2$ & TSA, R2A & UnStressed, stressed & Actinobacteria & Microbacterium hatanonis & 99.917 & - & - \\
\hline CP3 & TSA & UnStressed, stressed & Actinobacteria & Rhodococcus cercidiphylli & 99.439 & - & + \\
\hline $\mathrm{CP} 4$ & TSA, R2A & UnStressed, stressed & Actinobacteria & Microbacterium oxydans & 99.762 & - & + \\
\hline CP5 & TSA & UnStressed, stressed & Actinobacteria & Rhodococcus qingshengii & 100.000 & + & + \\
\hline CP6 & TSA, R2A & UnStressed & Gamma-proteobacteria & Pseudomonas peli & 100.000 & NA & NA \\
\hline CP7 & TSA & UnStressed & Alpha-proteobacteria & Sphingopyxis bauzanensis & 99.129 & - & + \\
\hline CP8 & TSA, R2A & UnStressed, stressed & Actinobacteria & Leucobacter luti & 98.638 & + & - \\
\hline CP9 & TSA & UnStressed, stressed & Actinobacteria & Dietzia maris & 99.759 & + & + \\
\hline
\end{tabular}


Table 2

Bacterial counts of broth co-culture assays after $48 \mathrm{~h}$ incubation. Each assay was run in triplicate.

\begin{tabular}{llll}
\hline Isolates & Pathogens & $\begin{array}{l}\text { Mean count } \\
\text { of isolates }\end{array}$ & $\begin{array}{l}\text { Mean count } \\
\text { of pathogens }\end{array}$ \\
\hline CP1 & F. columnare & $4.84 \times 10^{9}$ & 0 \\
CP1 & F. psychrophilum & $3.63 \times 10^{10}$ & 0 \\
CP3 & F. psychrophilum & $5.53 \times 10^{10}$ & 0 \\
CP4 & F. psychrophilum & $7.1 \times 10^{10}$ & 0 \\
CP5 & F. columnare & $8.7 \times 10^{10}$ & 0 \\
CP5 & F. psychrophilum & $6 \times 10^{11}$ & 0 \\
CP7 & F. psychrophilum & $1.39 \times 10^{11}$ & 0 \\
CP8 & F. columnare & $2.37 \times 10^{11}$ & 0 \\
CP9 & F. columnare & $8.33 \times 10^{10}$ & 0 \\
CP9 & F. psychrophilum & $7.73 \times 10^{10}$ & 0 \\
NA & F. columnare & NA & $5 \times 10^{9}$ \\
NA & F. psychrophilum & NA & $3 \times 10^{9}$ \\
\hline
\end{tabular}

transfer on AO agar plates, although pathogen growth was clearly observed in control plates (Table 2). The antagonistic effect observed in broth co-culture thus further validates the probiotic potential of all the eight isolates tested in agar diffusion assays.

\subsection{Screening for antagonistic effect of mucus protein}

Mucus of 43 fish was mixed, sterilized and spread on AO agar plate with $5 \mu \mathrm{L}$ of each pathogen to test for the presence of antagonistic effect caused by the secretion of antibacterial peptides. Morphological analysis of colonies showed no contamination by bacterial strains coming from mucus or other sources. Only colonies of the two pathogens were found. Each pathogen showed a better growth with mucus addition, especially for $F$. psychrophi$\operatorname{lum}\left(p<2.2 \times 10^{-16}\right)$.

\subsection{In vivo antagonism against $F$. columnare}

Seven strains with in vitro inhibitory activity against the two pathogens were mixed in order to be used in coculture for the in vivo experiment for logistical reasons. Mortality differed between the two conditions (cf Fig. 1). The first death occurred on day 4 in the control tanks but it occurred one day later with the treatment. The mortality rate stabilized at day 17 in the control and day 18 with the

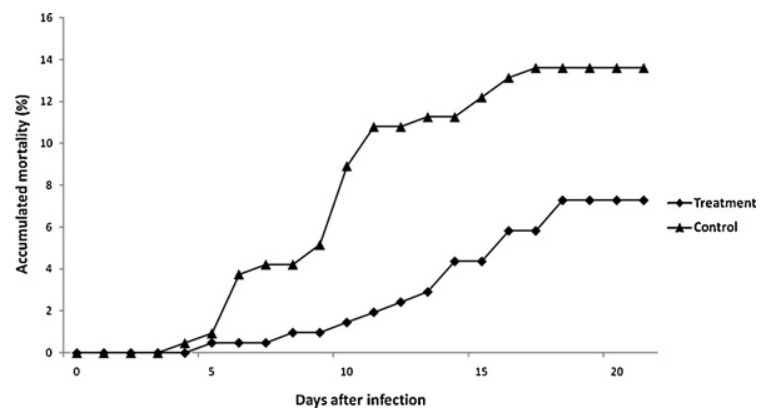

Fig. 1. Accumulated mortality of brook charr (all family taken together) infected by Flavobacterium columnare and treated with probiotics candidates. Probiotic culture was added to the tanks during the infection. probiotic treatment. The probiotic addition significantly reduced the mortality in the test tank $(p<0.001)$. The four families responded differently to the infection and to the probiotic treatment $(p<0.001)$ (cf Fig. 2). The family S9 exhibited a very high sensitivity to infection (24\% of death in control tanks), S1 and S10 families showed an intermediate response ( $12.9 \%$ and $12.8 \%$ of death in control tanks), and S9 family was strongly resistant (4.4\% of death in control tanks) to columnaris disease. No significant difference was observed between duplicates ( $p=0.47)$.

\section{Discussion}

F. columnare and F. psychrophilum are known to be two major pathogens in salmonid farming (Bernardet, 1997). Actually, the only way to prevent and treat infections caused by these two pathogens consists in the addition of $\mathrm{NaCl}$, formaldehyde or addition of antibiotics. However, various antibiotic resistance genes have rapidly invaded pathogen strains when fish were treated with antibiotics (Thomas-Jinu and Goodwin, 2004). To our knowledge, this study is the first that combines probiotic screening in skin microflora of brook charr, screening for the presence of inhibitory compounds in charr skin mucus, and more importantly, in vivo validation.

Nine bacterial strains were isolated and identified by cultivable methods with TSA and R2A media. These strains represent $0.03-1.8 \%$ of the total microbiota present in skin mucus of brook charr (Boutin et al., unpublished). This result can be explained by the difficulty to cultivate environmental bacteria. Indeed, Amann et al. (1990) estimated that no more than $1 \%$ of the environmental bacterial communities are cultivable. In the present study, the predominant bacterial group isolated from brook charr skin microbiota was composed of three genera of Actinobacteria (Microbacteriaceae, Nocardiaceae, Dietziaceae). Actinobacteria are known to be an abundant group in soil (Madigan et al., 1996) but are also reported to be very abundant in freshwater (Glockner et al., 2000). This suggests that predominance of Actinobacteria in our mucus samples can be explained by the influence of surrounding water bacterial community on fish mucus (Cahill, 1990).

Seventy-five percent and 50\% of the skin isolates had antagonistic effects against $F$. psychrophilum and $F$. columnare, respectively. Results from broth culture assays clearly indicate that all seven strains have antagonistic effects on the growth and the survival of the two pathogens. The results of the agar diffusion assays show that the mechanism involved in antagonistic effect is a competitive exclusion or a synthesis of non-diffusible antimicrobial. In this respect, no inhibition clearing was observed on agar plates but growth circles were present. The seven strains grew quickly during the first $48 \mathrm{~h}$, despite the fact that pathogens had already colonized all the media.

At first sight, the inhibition of growth and survival along with the absence of inhibitory compounds in skin mucus, support the competitive exclusion hypothesis. This concept of suppression of pathogens by the development of resident bacteria was first suggested by Nurmi and Rantala 
S1

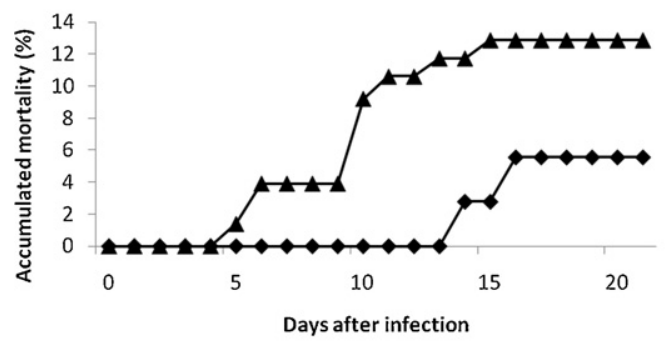

S9

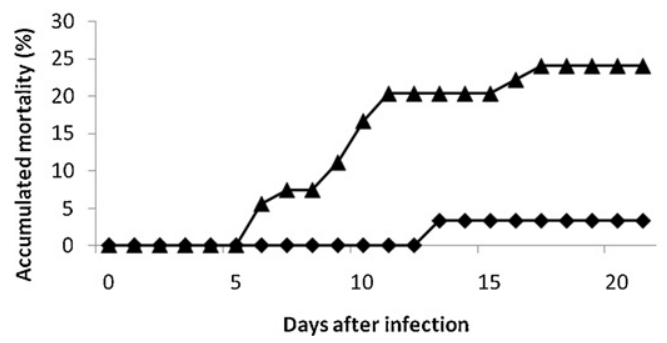

S5

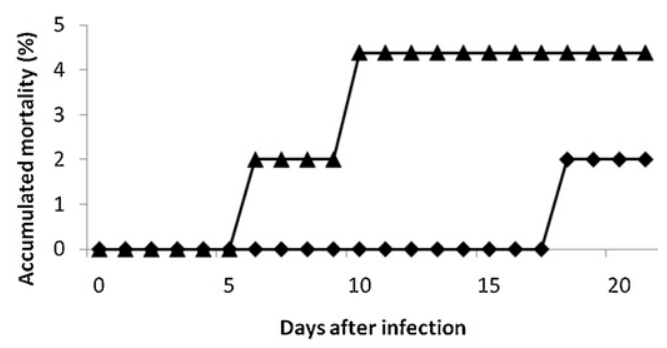

S10

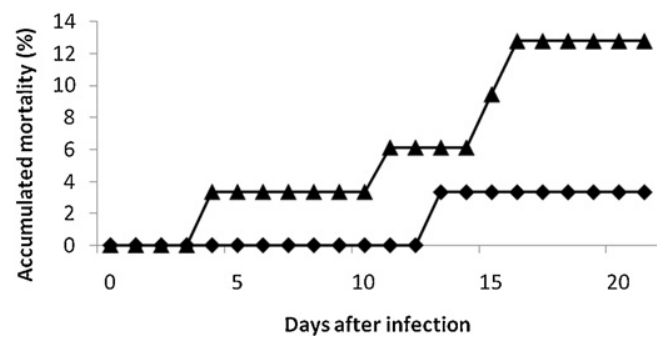

Fig. 2. Accumulated mortality for the four families of brook charr infected by Flavobacterium columnare and treated with probiotics candidates. Probiotic culture was added to the tanks during the infection.

(1973) in birds. The competitive exclusion exerted by probiotics against pathogens was also reported in fish, crustaceans, and other aquatic organisms (Balcázar et al., 2004). Competitive exclusion is the most promising mode of probiotic action because it involves many different processes and factors which are very important in microbial dynamics (Smith, 1993). In order to become more competitive, pathogens need to evolve and to gain new functions. Each of these new functions facing a single process implied in the competition. On the contrary, when competitors inhibit growth by secretion of a single antimicrobial agent, the pathogen needs to acquire only one specific resistance gene to this specific antimicrobial agent (Moriarty, 1998). Furthermore, horizontal gene transfers mediated by plasmid vehicles favor quick and frequent acquisitions of new antimicrobial resistance (Sørum, 2006). However, in a competitive exclusion interaction, pathogen needs to evolve more than a single resistance gene. This mechanism of adaptation is slower than a single plasmid transfer, therefore maintaining the status quo with the competing probiotic agent, as formalized in the red queen theory (van Valen, 1973).

The survival inhibition in the broth assay suggests a non-diffusible antimicrobial compound (Oliveira et al., 2008). The target of bacteriocin is the cytoplasmic membrane, but Gram-negative bacteria like Flavobacteria do have a protective barrier provided by the lipopolysaccharide of the outer membrane. However, some conditions can disrupt the integrity of this barrier and increase the effectiveness of bacteriocin against gram-negative bacteria (Stevens et al., 1991; Mortvedt-Abildgaard et al., 1995). The advantage of bacteriocin and other protein-like compounds is their sensitivity to digestion enzymes or proteases activity. Indeed, those compounds are easily degradable and safe for human consumption, which is not the case for antibiotics (Phillips et al., 2004; Courvalin, 2006). Further works to isolate and to identify those compounds are necessary to clearly identify the mechanisms involve in the in vitro antagonisms.

Our seven candidates fulfilled the three criteria for a subsequent in vivo validation experiment. First, they were all isolated from the resident community of skin mucus. Second, they were able to adhere and to colonize the mucus. Third, they all exerted antagonistic effects against pathogens by competitive exclusion for nutrient and/or synthesis of antimicrobial compounds (Verschuere et al., 2000). The addition of those probiotics in water tanks significantly decreased the fish mortality, which indicates a good agreement between our in vitro experiment and the in vivo experiment in contrast to many previous studies (Reddy et al., 1994; Gram et al., 2001). However, we just tested the effect in vivo against $F$. columnare because the infection occurred naturally after a stress due to the handling and not to a challenge against the pathogen itself. Furthermore, the four fish families showed different intensity of response to the treatment. A decrease of mortality occurred in all the families. Strikingly, the most important decrease occurred in the most sensitive family. This last result confirms previous observations on $S$. fontinalis, showing that some families are more sensitive than other to opportunistic infections (Bastien, 2009) and also strongly suggests that host genotype controls the efficiency of the probiotic effect on the pathogen. Knowing that microbiota composition is directly influenced by the host genotype (Turnbaugh et al., 2007), we can therefore hypothesize that some host genotypes are more tolerant to mutualism and let the probiotic colonize their skin mucus. The hosted probiotic will in turn confer a best protection to its host. This mechanism is the basis of symbiosis and mutualism. 


\section{Conclusion}

Our results indicate that isolation of host specific strains is easily manageable and cost effective in fish. To this respect, these probiotic strains exhibited high survival rate after freezing at $-80{ }^{\circ} \mathrm{C}$ with half volume of glycerol (data not shown). Seven of the nine strains collected from unstressed fish exerted strong exclusive competition against both $F$. psychrophilum and/or $F$. columnare, which suggests they are all promising probiotic candidates. Agar diffusion assays, combined with broth culture assays and the screening of inhibitory compounds in mucus, have clearly demonstrated that seven of our eight strains isolated from brook charr skin mucus were able to exclude both $F$. columnare and/or F. psychrophilum. Nevertheless, we were not able to clearly identify the mechanisms involved in the exclusion. Two non-exclusive hypotheses persist: (i) competition for nutrients; (ii) synthesis of bacteriocin or other antimicrobial compounds. The use of these seven probiotics in vivo clearly reduced the mortality, therefore demonstrating the curative effect of these host specific strains. These results show unambiguously that using of probiotics is a really manageable way to efficiently reduce mortality due to opportunistic infections. Moreover, the efficiency of probiotic action could be improved by combining a genetic selection program enhancing the relationship between fish and probiotics. Further works on the impact of these probiotics on the microbial load of fish and water are in progress in order to more-specifically examine the antagonistic mechanisms observed in this study.

\section{Acknowledgments}

We thank S. Pavey, M. Evans, the associate editor of Veterinary Microbiology, and two anonymous reviewers for critical reading of the manuscript. This work was financially supported by a Partnership grant (Strategic program) of the "Conseil de recherches en sciences naturelles et en génie" (CRSNG) to LB, ND and CA and the "Formation orientée vers la nouveauté, la collaboration et l'expérience en recherche" program (FONCER). This is a contribution to the research program of Réseau Aquaculture Québec (RAQ). The authors are very grateful to the staff of the "Laboratoire Regional des Sciences Aquatiques" for their invaluable help in developing the bio-filters and culturing bacterial strains used in this experiment.

\section{References}

Amann, R.I., Binder, B.J., Olson, R.J., Chisholm, S.W., Devereux, R., Stahl, D.A., 1990. Combination of $16 \mathrm{~S}$ rRNA-targeted oligonucleotide probes with flow cytometry for analyzing mixed microbial populations. Applied and Environmental Microbiology 56 (6), 1919-1925.

Anacker, R.L., Ordal, E.J., 1959. Studies on the Myxobacterium chondrococcus columnaris: II. Bacteriocins. Journal of Bacteriology 78 (1), 3340.

Balcázar, J., de Blas, I., Ruiz-Zarzuela, I., Vendrell, D., Muzquiz, J., 2004. Probiotics: a tool for the future of fish and shellfish health management. Journal of Aquaculture in the Tropics 19, 239-242.

Bastien, A., 2009. Evaluation of a selection program and identification of physiological traits linked to anadromous in the brook trout (Salvelinus fontinalis). $\mathrm{PhD}$ thesis.
Bernardet, J.-F., Bowman, J., 2006. In: Dworkin, M., Falkow, S., Rosenberg E., Schleifer, K.-H., Stackebrandt, E. (Eds.), The Genus Flavobacterium. The Prokaryotes. Springer, New York, pp. 481-531.

Bernardet, J.F., 1997. Flavobacterium and Flexibacter Infections: Immunization with Bacterial Antigens.

Bernardet, J.F., Grimont, P.A.D., 1989. Deoxyribonucleic acid relatedness and phenotypic characterization of Flexibacter columnaris sp nov. nom. rev., Flexibacter psychrophilus sp. nov., nom. rev., and Flexibacter maritimus Wakabayashi, Hikida, and Masumura 1986. International Journal of Systematic Bacteriology 39 (3), 346-354.

Cahill, M.M., 1990. Bacterial flora of fishes: a review. Microbial Ecology 19 (1), 21-41.

Courvalin, P., 2006. Antibiotic resistance: the pros and cons of probiotics. Digestive and Liver Disease 38 (Suppl. 2), S261-S265.

FAO, 2007. World Aquaculture Production of Fish, Crustaceans, Molluscs, etc., by Principal Producers in 2007.

Glockner, F.O., Zaichikov, E., Belkova, N., Denissova, L., Pernthaler, J., Pernthaler, A., Amann, R., 2000. Comparative 16S rRNA analysis of lake bacterioplankton reveals globally distributed phylogenetic clusters including an abundant group of actinobacteria. Applied and Environmental Microbiology 66 (11), 5053-5065.

Gram, L., Løvold, T., Nielsen, J., Melchiorsen, J., Spanggaard, B., 2001. In vitro antagonism of the probiont Pseudomonas fluorescens strain $\mathrm{AH} 2$ against Aeromonas salmonicida does not confer protection of salmon against furunculosis? Aquaculture 199 (1-2), 1-11.

Gram, L., Melchiorsen, J., 1996. Interaction between fish spoilage bacteria Pseudomonas sp and Shewanella putrefaciens in fish extracts and on fish tissue. Journal of Applied Microbiology 80 (6), 589-595.

Lane, D.J., Pace, B., Olsen, G.J., Stahl, D.A., Sogin, M.L., Pace, N.R., 1985 Rapid determination of $16 \mathrm{~S}$ ribosomal RNA sequences for phylogenetic analyses. Proceedings of the National Academy of Sciences of the United States of America 82 (20), 6955-6959.

Madigan, M.T., Martinko, J.M., Parker, J., 1996. Brock Biology of Microorganisms. .

Marchesi, J.R., Sato, T., Weightman, A.J., Martin, T.A., Fry, J.C., Hiom, S.J., Wade, W.G., 1998. Design and evaluation of useful bacterium-specific PCR primers that amplify genes coding for bacterial 16S rRNA. Applied and Environmental Microbiology 64 (2), 795-799.

Merrifield, D.L., Dimitroglou, A., Foey, A., Davies, S.J., Baker, R.T.M., Bøgwald, J., Castex, M., Ringø, E., 2010. The current status and future focus of probiotic and prebiotic applications for salmonids? Aquaculture 302 (1-2), 1-18

Moriarty, D.J.W., 1998. Control of luminous Vibrio species in penaeid aquaculture ponds? Aquaculture 164 (1-4), 351-358.

Mortvedt-Abildgaard, C., Nissen-Meyer, J., Jelle, B., Grenov, B., Skaugen, M., Nes, I., 1995. Production and pH-dependent bactericidal activity of lactocin S, a lantibiotic from Lactobacillus sake L45. Applied and Environment Microbiology 61 (1), 175-179.

Nematollahi, A., Decostere, A., Pasmans, F., Haesebrouck, F., 2003. Flavobacterium psychrophilum infections in salmonid fish. Journal of Fish Diseases 26 (10), 563-574.

Nurmi, E., Rantala, M., 1973. New aspects of salmonella infection in broiler production. Nature 241 (5386), 210-211.

Oliveira, R.B.P., Oliveira, d.L.A., Gloria, B.M.A., 2008. Screening of lactic acid bacteria from vacuum packaged beef for antimicrobial activity. Brazilian Journal of Microbiology 39, 368-374.

Phillips, I., Casewell, M., Cox, T., De Groot, B., Friis, C., Jones, R., Nightingale, C., Preston, R., Waddell, J., 2004. Does the use of antibiotics in food animals pose a risk to human health? A critical review of published data. Journal of Antimicrobial Chemotherapy 53 (1), 28-52.

Rangdale, R.E., Richards, R.H., Alderman, D.J., 1997. Minimum inhibitory concentrations of selected antimicrobial compounds against Flavobacterium psychrophilum the causal agent of rainbow trout fry syndrome (RTFS)? Aquaculture 158 (3-4), 193-201.

Reddy, M.S., Hynes, R.K., Lazarovits, G., 1994. Relationship between invitro growth-inhibition of pathogens and suppression of preemergence damping-off and postemergence root-rot of white bean seedlings in the greenhouse by bacteria. Canadian Journal of Microbiology 40 (2), 113-119.

Schimel, J., Balser, T.C., Wallenstein, M., 2007. Microbial stress-response physiology and its implications for ecosystem function. Ecology 88 (6), 1386-1394.

Smith, V.H., 1993. Applicability of resource-ratio theory to microbial ecology. Limnology and Oceanography 38 (1), 239-249.

Sørum, H., 2006. Antimicrobial drug resistance in fish pathogens. In: Aarestrup, F.M. (Ed.), Antimicrobial Resistance in Bacteria of Animal origin. American Society for Microbiology Press, Washington, DC, pp. 213-238.

Spanggaard, B., Huber, I., Nielsen, J., Sick, E.B., Pipper, C.B., Martinussen, T., Slierendrecht, W.J., Gram, L., 2001. The probiotic potential against 
vibriosis of the indigenous microflora of rainbow trout. Environmental Microbiology 3 (12), 755-765.

Stevens, K.A., Sheldon, B.W., Klapes, N.A., Klaenhammer, T.R., 1991. Nisin treatment for inactivation of Salmonella species and other gramnegative bacteria. Applied and Environmental Microbiology 57 (12), 3613-3615.

Thomas-Jinu, S., Goodwin, A.E., 2004. Morphological and genetic characteristics of Flavobacterium columnare isolates: correlations with virulence in fish. Journal of Fish Diseases 27 (1), 29-35.

Timmerman, H.M., Koning, C.J.M., Mulder, L., Rombouts, F.M., Beynen, A.C., 2004. Monostrain, multistrain and multispecies probiotics - a comparison of functionality and efficacy. International Journal of Food Microbiology 96 (3), 219-233.
Turnbaugh, P.J., Ley, R.E., Hamady, M., Fraser-Liggett, C.M., Knight, R., Gordon, J.I., 2007. The human microbiome project. Nature 449 (7164), 804-810.

van Valen, L., 1973. A new evolutionary law. Evolutionary Theory 1, 1-30. Verschuere, L., Rombaut, G., Sorgeloos, P., Verstraete, W., 2000. Probiotic bacteria as biological control agents in aquaculture. Microbiology and Molecular Biology Reviews 64 (4), 655-671.

Wakabayashi, H., 1991. Effect of environmental conditions on the infectivity of Flexibacter columnaris to fish. Journal of Fish Diseases 14 (3), 279-290.

Williams, C.J., Kraus, F.W., 1963. Sterilization and storage of saliva. Journal of Dental Research 42 (6), 1416-1428. 